\title{
Phytotoxic impact of Parthenium hysterophorus L. on Macrotyloma uniflorum a pulse crop in a dry tropical environment, Bihar, India
}

\author{
Raj Shikha* \\ Department of Botany, Jai Prakash University, Chapra - 841301 (Bihar), India \\ A.K. Jha \\ Department of Botany, Jai Prakash University, Chapra - 841301 (Bihar), India \\ *Corresponding author. E-mail: shikharaj1990@gmail.com
}

\section{Article Info}

DOI:10.31018/jans.v10i4.1825

Received: July 10, 2018

Revised: September 11, 2018

Accepted: October 13, 2018

\section{How to Cite}

Shikha, R. and Jha, A.K. (2018). Phytotoxic impact of Parthenium hysterophorus I. on Macrotyloma uniflorum a pulse crop in a dry tropical environment, Bihar, India. Journal of Applied and Natural Science, 10(4): $1141-1148$ toxic to M.uniflorum than the stem extract of P.hysterophorus. The rate of seed germination and length of shoot differed significantly in different concentrations than the length of root, as indicated by Post HOC Test. The effect of plant parts i.e. root, stem and leaf; treatments i.e. different concentrations and interaction of plant parts and treatments were significantly differed at $p<0.000$. Generally the impacts of different parts were also significantly different at $p<0.000$. Thus, this study indicated that the leaf and root extracts are more toxic to $M$. uniflorum than the stem extract; and the rate of seed germination and shoot length were more affected than the root length. The seed germination and shoot growth in M. uniflorum are affected by leaf and root extracts of Parthenium.

Keywords: Phytotoxic effect, Parthenium hysterophorus, Macrotyloma uniflorum, Seed Vigour Index

\section{INTRODUCTION}

In India, Parthenium is considered as worst weed due to its allelopathic effects on crops and harmful effects on animals and human beings. It is spread in all states of India. It is called as "Scourge of India". In 2012 it has covered about 35 million ha of wasteland, cropland and forest lands in India (Kumar 2012). Parthenium has spread in all types of cereals, pulses, cash crops, vegetable crops, pastures, forests, plantations etc. Under suitable soil and moisture conditions Parthenium becomes dominant species and causes exclusion of beneficial plants. The invasive species having high capability to spread rapidly and high competitiveness are the major threats to the native species and ecosystem (Kathiresan et al. 2005). Parthenium colonizes wide range of habitats and any type of soil, wastelands, pastures, road sides, agricultural lands etc. The production of crop is affected by Parthenium. According to McGinley and Duffy (2011) invasive species rank second as a threat to biodiversity. P.hysterophorus had no place in the world' worst weed till 1977 and during 1987 it became one of the seven most dangerous weed of the world (Kumar 2015). According to Netsere (2015) allelopathy has many effects either positive or negative on many plant species by stimulating or inhibiting the surrounding herbaceous vegetation. Parthenium will become more problematic in future when $\mathrm{CO}_{2}$ levels will increase due to climatic change (Nguyen et al. 2017).

The allelopathic effects of different parts of Parthenium on seed germination and seedling growth have been evaluated in rice, maize, wheat, Artemisia dubia, wall ex. Ageratina adenophora and cultivated crucifers, R.sativus, B.compestris and B.oleracea, (Maharajan et al. 2007); Eragrostis tef (Tafera, 2002), Brassica sp. (Singh et al. 2005); onion and beans (Demissie et al. 2013); three native plants of Himachal Pradesh (Dogra and Sood, 2012); rice, wheat, chickpea, soybean and mustard (Karim and Forzwa 2010; Biswas 2010); Glycine max and Phaseolus vulgaris (Netsere and Mendesil, 2011); onion (Wakjira, 2009); Lettuca 
Shikha, R. and Jha, A.K. / J. Appl. \& Nat. Sci. 10 (4): 1141 -1148 (2018)

(Wakjira et al., 2005); maize, sorghum, multipurpose trees; pumpkin and tomato (Tamado et al. 2002); Alysicarpus glumaceus, Chloris gayana, Zea mays, barley, wheat, peas, Helianthus annus, Glycine max, Phaseolus vulgaris, sorghum, Eragrostis tef, rice, chickpea, soybean, mustard, Brassica, green gram, black gram, moth bean, cow pea etc. (Choesin and Boerner 1991; Tafera 2002; Bajwa et al. 2003; Singh et al. 2005; Maharajan et al. 2007; Kumar et al. 2008; Rashid et al. 2008; Biswas 2010; Netsere and Mendesil 2011; Clarence et al. 2013; Purohit and Pandya 2013; Devi et al. 2014; Netsere 2015) soybean and hericot bean (Netsere and Mendesil 2011); wheat (Khan et al. 2012); Zea mays (Devi and Dutta 2012); chili, tomato, brinjal (Jarvis et al., 1985); rice (Oudhia 1998); chickpea, mustard and linseed (Oudhia et al. 1997, Oudhia and Tripathi 1998); Allium cepa (Karim and Forzwa 2010; Biswas 2010; Demissie et al. 2013); Phaseolus mungo (Kumar and Kumar 2010); pumpkin and tomato (Guzman 1988); sunflower (Bajwa et al. 2004); Festuca arundinaceae, Digitaria sanguinalis (Peters and Zam 1981); wheat and associated weeds (Amin et al. 2007); Ocimum americanum (Batish et al. 2001); Vigna radiata and Phaseolus vulgaris (Afjal et al. 2000); cultivated and wild herbs;, maize (Pandey 1994); Brassica sp. (Rai 2013); sorghum (Rai 2015); chickpea and radish (Rajiv et al. 2013); tomato (Rao 1956); barley (Sarita et al. 2011); Arachis hypogea (Sharma and Bhutani 1988); P.vulgaris (Singh and Thapar 2003); onion and bean (Srivastava et al. 1985); barley (Kumar 2015); Oriza sativa and Triticum aestivum (Singh and Sangeeta 1991); soyabean (Bhatt et al. 1994); barley, wheat and peas (Srivastava et al. 1985); wheat (Patil and Hedge 1988); cabbage (Kohli et al. 1985); Lepidium (Amin et al. 2007); C.aeritinum, P.sativum and C.cajan (Singh et al. 2014); and Phaseolus mungo, Cicer aeritinum, Pisum sativum, Cajanus cajan, Zea mays Brassica nigra, Triticum aestivum (Shikha and Jha 2016 a, b, c, d; 2017 a, b; 2018 a, b). Tamado (2000) has reported $90 \%$ loss in the yield of sorghum whereas Gnanavel and Natrajan (2013) have reported $40 \%$ loss in yield of crops and causing socio-economic impacts. M.uniflorum is a pulse crop which have many medicinal uses. Macrotyloma uniflorum is an annual plant, densely growing, low-growing of climbing, slender, herbaceous legume reaching $30-60 \mathrm{~cm}$ in height. The stems, leaves and husks are used as fodder or green manure and seeds are fed to cattle and horses. It is anti-bacterial, antifungal and antihyper glycemic in nature. It is rich in antioxidants. It is useful in preventing constipation, lowering blood pressure, good for weight loss, improves heart health, increases sperm count, lowers cholesterol levels, keeps body warm during winter and useful in treatment of urinary stones
(Ranasinghe and Ediriweera 2017).

Thus, the present study was aimed to evaluate the impact of different concentrations of leaf, stem and root aqueous extracts of P.hysterophorus on the rate of seed germination and growth of seedlings of Macrotyloma uniflorum in laboratory condition.

\section{MATERIALS AND METHODS}

Parthenium hysterophorus has invaded the Jai Prakash University campus of about 240 ha area in just ten years. Earlier the whole area was a cropland. The study site is situated between $25^{\circ}$ $36^{\prime}-26^{0} 15^{\prime} \mathrm{N}$ latitude and $84^{\circ} 25^{\prime}-85^{\circ} 15^{\prime} \mathrm{E}$ longitude in the southern part of the newly - created Saran Division of North Bihar. Total area of the Saran district is $2641 \mathrm{sq}$. $\mathrm{km}$.

After establishment of the University campus and abandonment of cropping P.hysterophorus invaded the whole area in just ten years. It is classified as below:

Division: Eukaryota

Kingdom: Plantae

Phyllum: Spermetophyta

Sub - Phyllum: Angiospermae

Class: Dicotyledonae

Order: Asterales

Family: Asteraceae

Genus: Parthenium

Species: hysterophorus

Parthenium grows luxuriantly in wastelands, public lawns, orchards, forestlands, flood plains, agricultural areas, urban areas, overgrazed pastures, industrial areas, playgrounds, roadsides, railway tracks and residential plots. Drought and subsequent reduced pasture cover creates the ideal situation for the Parthenium weed to establish itself. Although it is capable of growing in moist soil types, it is most dominant in alkaline, clay loam soils (Kaur et al. 2014; Tafera 2002). Plant samples were collected from the University campus from vegetative phase of P.hysterophorus during the period 2017. Root, stem and leaves were separated and air dried in shade and crushed with the help of laboratory blender. Stems and roots were cut into small pieces and dried samples were grounded using laboratory blender. The leaves were dried in shade and then crushed with the help of laboratory blender. $35 \mathrm{gm}$. of leaf, stem and root powder was soaked with $100 \mathrm{ml}$ sterilized water for $24 \mathrm{~h}$ at room temperature. After soaking solutions were filtered through whatman's filter paper and final volume was adjusted for further use. The extract was considered as stock solution and a series of solutions with different strengths $(15 \%, 25 \%, 50 \%, 75 \%$ and $100 \%)$ were prepared by dilution with distilled water. Dried samples were powdered A separate control condition was set up by using only distilled water. Experiments were set up in petri dishes covered with 
whatman's filter paper. For each treatment ten replicates were maintained and in each petridish ten seeds of Macrotyloma uniflorum was placed. Distilled water was added when needed in petridishes. The rate of seed germination, length of root and shoot were determined after seven days of setting up of the experiment. Seed Vigour Index (SVI) was calculated by using the following formula:

SVI $=($ Length of root + Length of shoot $) \times$ Seed germination \%

Data collected were statistically analysed by using the SPSS (Statistical Package for the Social Sciences) programme through Pearson Correlation Coefficient and Tukey HSD, Post Hoc Tests.

\section{RESULTS AND DISCUSSION}

Seed germination rate (\%): The rate of seed germination in control condition varied from 93\% to $100 \%$ whereas in aqueous extracts of leaf, stem and root of different concentrations it varied from $0 \%$ to $96 \% ; 87 \%$ to $98 \%$; and $0 \%$ to $93 \%$, respectively (Table 1 ). The rate of seed germination decreased from 4 to $100 \%$ in aqueous extract of leaf; $1.08 \%$ to $6.45 \%$ in stem extract; and 19.35 to $100 \%$ in root extract (Table 2). Marwat et al. (2015) have collected data on chemicals isolated from Parthenium by various authors and about 123 compounds have been reported. All parts of Parthenium (leaves, stems, leaf hairs, flowers, pollen grains etc.) contain toxic and inhibitory constituents such as terpenoids, sesquiterpene lactones , volatile oils, flavanoides (Barnes et al., 2007; Pareek et al., 2011); phenolic derivatives (Parsons and Cuthbertson 2001); Parthenin (Zhou et al., 2011); caffic, vanllic , ferfulic, chlorogenic and anisic acids (Parsons and Cuthbertson, 2001). Parthenin is one of the important alkaloids which is responsible for phytotoxic and allelopathic effect of Parthenium. The visible effects of allelochemicals on other plants include inhibition or retardation of germination rate; darkening and swelling of seeds; reduction of root and shoot length; swelling or necrosis of root tips; curling of the root axis; decoloration, lack of root hairs; increased number of seminal roots; reduced dry weight accumulations; and lowered reproductive capacity (Bhadoria 2011). Khalaj et al. (2013) reported that secondary metabolites are released through volatilization, leaching, root exudation and decomposition of plant residues in the soil. Bhowmik et al. (2007) have reported that parthenin is the active principal component among all the chemicals secreted by $P$.hysterophorus which have the strong allelopathic

Table 1. Seed germination rate, length of root, shoot and Seed Vigour Index in M.uniflorum in different concentrations of leaf, stem and root extract of P.hysterophorus.

\begin{tabular}{|c|c|c|c|c|c|c|c|}
\hline \multirow{2}{*}{ Extracts } & \multirow{2}{*}{ Growth parameters } & \multirow{2}{*}{ Control } & \multicolumn{5}{|c|}{ Concentration } \\
\hline & & & $15 \%$ & $25 \%$ & $50 \%$ & $75 \%$ & $100 \%$ \\
\hline \multirow{4}{*}{ Leaf Extract } & Seed Germination (\%) & 100 & 96 & 86 & 73 & 33 & 0 \\
\hline & Root Length $(\mathrm{cm})$ & 5.19 & 3.15 & 3.03 & 1.89 & 0.49 & 0 \\
\hline & Shoot Length $(\mathrm{cm})$ & 6.04 & 4.82 & 2.64 & 2.27 & 0.46 & 0 \\
\hline & SVI & 1123 & 765 & 488 & 304 & 31 & 0 \\
\hline \multirow{4}{*}{ Stem Extract } & Seed Germination (\%) & 93 & 98 & 92 & 91 & 92 & 87 \\
\hline & Root Length $(\mathrm{cm})$ & 6.8 & 6.62 & 6.35 & 5.3 & 5.59 & 9.85 \\
\hline & Shoot Length $(\mathrm{cm})$ & 10.16 & 10.01 & 9.47 & 8.68 & 7.36 & 6.84 \\
\hline & SVI & 1577 & 1630 & 1455 & 1272 & 1164 & 1452 \\
\hline \multirow{4}{*}{ Root Extract } & Seed Germination (\%) & 93 & 75 & 78 & 56 & 10 & 0 \\
\hline & Root Length $(\mathrm{cm})$ & 4.78 & 3.47 & 3.03 & 1.13 & 0.06 & 0 \\
\hline & Shoot Length $(\mathrm{cm})$ & 8.69 & 5.63 & 5.98 & 2.51 & 0.17 & 0 \\
\hline & SVI & 1253 & 683 & 703 & 204 & 2.3 & 0 \\
\hline
\end{tabular}

Table 2. Per cent increase or decrease in seed germination rate and growth parameters in M.uniflorum in different concentrations of leaf, stem and root extract of P.hysterophorus.

\begin{tabular}{lllllll}
\hline \multirow{2}{*}{ Extracts } & \multirow{2}{*}{ Growth parameters } & \multicolumn{2}{l}{ Concentration } & & & \\
\cline { 3 - 6 } & & $\mathbf{1 5 \%}$ & $\mathbf{2 5 \%}$ & $\mathbf{5 0 \%}$ & $\mathbf{7 5 \%}$ & $\mathbf{1 0 0 \%}$ \\
\hline \multirow{5}{*}{ Leaf Extract } & Seed Germination (\%) & -4 & -14 & -27 & -67 & -100 \\
& Root Length (cm) & -39.31 & -41.62 & -63.58 & -90.56 & -100 \\
& Shoot Length (cm) & -19.7 & -56.29 & -62.42 & -92.38 & -100 \\
& SVI & -23.53 & -62.23 & -72.49 & -97.48 & -100 \\
& Seed Germination (\%) & 5.38 & -1.08 & -2.15 & -1.08 & -6.45 \\
\multirow{5}{*}{ Stem Extract } & Root Length (cm) & -2.65 & -6.62 & -22.06 & -17.79 & 44.85 \\
& Shoot Length (cm) & -1.48 & -6.79 & -14.57 & -27.6 & -32.68 \\
& SVI & 3.33 & -7.72 & -19.34 & -26.21 & -7.94 \\
& Seed Germination (\%) & -19.35 & -16.13 & -39.78 & -89.25 & -100 \\
\multirow{5}{*}{ Root Extract } & -27.41 & -36.61 & -76.36 & -98.74 & -100 \\
& Root Length (cm) & -35.21 & -31.19 & -71.12 & -98.04 & -100 \\
& Shoot Length (cm) & -32.44 & -33.11 & -72.98 & -98.29 & -100 \\
\hline \hline
\end{tabular}


Table 3. Tukey HSD and significance levels after statistically analysing the data collected by Post HOC tests.

\begin{tabular}{llccc}
\hline SI. No. & & Seed Germination Rate (\%) & $\begin{array}{c}\text { Root Length } \\
\text { (cm) }\end{array}$ & $\begin{array}{c}\text { Shoot length } \\
\text { (cm) }\end{array}$ \\
\hline 1 & Plant Parts & 0.000 & 0.000 & 0.000 \\
2 & Treatments & 0.000 & 0.003 & 0.000 \\
3 & Plant Parts $\times$ Treatments & 0.000 & 0.039 & 0.000 \\
4 & Leaves $\times$ Stem & 0.000 & 0.000 & 0.000 \\
5 & Leaves $\times$ Root & 0.000 & 0.945 & 0.000 \\
6 & Stem $\times$ Root & 0.000 & 0.000 & 0.000 \\
7 & Control / 15\% & 0.432 & 0.801 & 0.000 \\
8 & Control / 25\% & 0.027 & 0.622 & 0.000 \\
9 & Control / 50\% & 0.000 & 0.033 & 0.000 \\
10 & Control / 75\% & 0.000 & 0.003 & 0.000 \\
11 & Control / 100\% & 0.114 & 0.000 \\
12 & $15 \% / 25 \%$ & 0.000 & 1.000 & 0.153 \\
13 & $15 \% / 50 \%$ & 0.817 & 0.489 & 0.000 \\
14 & $15 \% / 75 \%$ & 0.000 & 0.115 & 0.000 \\
15 & $15 \% / 100 \%$ & 0.000 & 0.790 & 0.000 \\
16 & $25 \% / 50 \%$ & 0.000 & 0.683 & 0.000 \\
17 & $25 \% / 75 \%$ & 0.004 & 0.218 & 0.000 \\
18 & $25 \% / 100 \%$ & 0.000 & 0.920 & 0.000 \\
19 & $50 \% / 75 \%$ & 0.000 & 0.970 & 0.000 \\
20 & $50 \% / 100 \%$ & 0.000 & 0.997 & 0.000 \\
21 & $75 \% / 100 \%$ & 0.000 & 0.804 & 0.848 \\
\hline
\end{tabular}

and allergic effect. Different concentrations of parthenin have been reported in different plant parts on dry weight basis such as leaf $(3.40 \%)$, stem $(0.12 \%)$, flower $(1.08 \%)$ and trichomes $(1.20 \%)$. Under laboratory conditions, parthenin released by aquous extraction of freash leaf material of P.hysterophorus proved to have $16-100 \%$ relative role (Belz et al. 2007). Dogra and Sood (2012) analysed the phytotoxicity of Parthenium on three native plants of Himachal Pradesh under in - vivo condition and found that soil mixed with residues of Parthenium adversely affect the per cent of seed germination and seedling growth. Maharajan et al. (2007) have indicated that increase in concentration of extract was invariably associated with decrease in germination and seedling characteristics of the crops. Veena and Maurya (2012) have reported that due to inhibitory role of mainly parthenin present in P.hysterphorus inhibits the germination and growth of plants such as pasture grasses, cereals, vegetables and other plant species. Rajendiran (2005) and Sorecha et al. (2017) have reported that allelochems present in the Parthenium plant parts could prevent the embryonic development and embryo growth and caused death. The present study revealed that increase in the concentration of Parthenium plant extracts inhibited the germination of M.uniflorum. Similar findings have been reported by Sorecha et al. (2017) in case of peanut and soybean in Ethiopia. The impact of inhibition in the rate of seed germination in M.uniflorum by extracts of leaf, stem and root it was leaf extract that highly reduced the ger- mination followed by root than stem. It may be because leaf of Parthenium contains more parthenin than root and stem. Complete failure in seed germination in M.uniflorum was observed in $100 \%$ concentrations of leaf and root extracts of Parthenium (Table 1). Tafera (2002) has also reported that aqueous extracts of Parthenium leaf and flower inhibited completely seed germination in Eragrostis teff. The higher the concentration of Parthenium plant parts extracts, the higher the influences on the germination of M.uniflorum was observed.

Root length: The root length values in M.uniflorum in different concentrations of leaf, stem and root of Parthenium ranged from 0.0 to $3.15 \mathrm{~cm}$; 5.3 to $9.85 \mathrm{~cm}$; and 0.0 to $3.47 \mathrm{~cm}$, respectively. The decrease in root length varied from $39.31 \%$ to $100 \%$; 2.65 to $44.85 \%$; and 27.41 to $100 \%$, respectively. The leaf extract was recorded more inhibitory for root length in M.uniflorum followed by root extract than stem extract of Parthenium.

Rashid et al. (2008) have reported root extract of Parthenium reduces the germination and growth of barley and maize. Picman and Picman (1984), and Mersie and Singh (1988) have suggested that water soluble allelochemicals parthenin is the cause of high degree of phytotoxicity of Parthenium residues.

Shoot length: The shoot length values in M. uniflorum in different concentrations of leaf extract of Parthenium varied from 0.0 to $4.82 \mathrm{~cm}$; in stem extract from 6.84 to $10.01 \mathrm{~cm}$ and in root extract 
from 0.0 to $5.98 \mathrm{~cm}$ (Table 1). The per cent decrease in shoot length in M.uniflorum varied from $19.7 \%$ to $100 \% ; 1.48$ to $32.68 \%$ and 31.19 to $100 \%$, respectively, in leaf, stem and root extracts of Parthenium. The germination and growth of agricultural crops like rice, wheat, maize, pigeonpea, blackgram, sorghum etc. are inhibited by the allelopathic effect of P.hysterophorus. Nodulation in legumes due to inhibition of activity of nitrogen fixing and nitrifying bacteria such as Rhizobium, Actinomycetes, Azitobacter and Azospirillum is affected by P.hysterophorus. Wakjira et al. (2009) reported that the adverse effect of residues on seed germination and plant growth could be the result of immobilization of large amounts of nutrients by micro-organisms involved in decomposition, by allelochemicals or both. Upadhyay et al. (2013) have evaluated the ecological impacts of $P$.hysterophorus invasion in saline soil in India. Anwar et al. (2016) have reported phytotoxic effects of leaf powder and aquous extract of P.hysterophorus on seed germination and seedling growth in Avena fatua, Rumex dentatus, Helianthus annus, Zea mays and Triticum estivum in Pakistan. Singh et al. (2005) have shown the strong positive correlation between extract concentration of residue of Parthenium and reduction in seedling length of Brassica species.

Seed vigour index (SVI): The seed vigour index values of M.uniflorum in leaf, stem and root extracts of Parthenium varied from 0.0 to $765 ; 1164$ to 1630 and 0.0 to 683 in different treatments (Table 1). The seed vigour index values decreased from $23.53 \%$ to $100 \% ; 7.72$ to $26.21 \%$ and 32.44 to $100 \%$, respectively, in leaf, stem and root extracts of Parthenium compared to control treatment.

Parthenium inhibited the growth of water hyacinth due to loss of dehydrogenase activity in roots, damage of cellular membrane and loss of chlorophyll in leaves (Pandey 1996). Similarly Batish et al. (2002) have reported that parthenin inhibited mung bean growth by affecting protease and peroxidase enzyme activities, respiration and protein content. In the present study, thus, the parthenin and other phenolic compounds including ferulic, caffeic, chlorogenic, vanillic and anisic acid reported by several researchers in Parthenium may be probably growth retardants in $M$. uniflorum.

\section{Conclusion}

The phytotoxic effects of different concentrations of aqueous extracts of leaf, stem and root of $P$.hysterophorus were recorded on seed germination and growth of M.uniflorum. Leaf and root extracts were more phytotoxic than the stem extract in the present study. Thus prevention and control of P.hysterophorus is needed. All control strategies of invasive species such as physical, chemical and biological should be integrated. A holistic approach having integrated long-term management programme should be carried out to control the weed. Coordination among social people, scientists, governments and NGO'S is needed including people awareness programme. To overcome the economic loss it is essential to use Parthenium alternatively in beneficial purposes such as biofertilizer, green manure, anticancer, pesticidal, antimicrobial, lervicidal, ovicidal, herbicidal etc. There is need to do clinical researches and investigations to establish Parthenium as a standard medicinal plant.

\section{ACKNOWLEDGEMENTS}

Authors are grateful to all the teaching members of Department of Botany, J.P. University, Chapra, Bihar for necessary help and support during our research work.

\section{REFERENCES}

1. Afjal, B., Bajwa, R. and Javaid, A. (2000). Allelopathy and V A mycorrhiza VII. Cultivation of Vigna radiata and Phaseolous vulgaris under allelopathic stress caused by Imperata cylindrical. Pak. J. Biol. Sci. 3:1926-8.

2. Amin, A., Rashid, H., Khan, M.A. and Khan, M.I. (2007). Allelopathic effect of Parthenium hysterophorus (L.) extracts on germination and growth of weeds. Proceedings of the 21th Asian Pacific Weed Science Society Conference. 2-6 Oct. Colombo, 14-18.

3. Anwar, T., Khalid, S., Saeed, M., Mazhar, R., Qureshi, H. and Rashid, M. (2016). Allelopathic interference of leaf powder and aqueous extracts of hostile weed: Parthenium hysterophorus (Asteraceae). Sci. Int, 4: 86-93.

4. Bajwa, R., Akhtar, J. and Javaid, A. (2003). Role of VAM in alleviating allelopathic stress of Parthenium hysterophorus on maize (Zea mays L.), Mycopath, 1 (1):15-30.

5. Bajwa, R., Shafique, S., Shafique, S. and Javaid, A. (2004). Effect of foliar spray of aqueous extract of Parthenium hysterophorus on growth of sunflower. Int. J. Agri. Bio. 3:474-478.

6. Batish, D.R., Singh, H.P., Kohli, R.K. and Kaur, S. (2001). Crop allelopathy and its role in ecological agriculture: Allelopathy in Agroecosystems. Binghamton, N.Y.: Haworth Press.

7. Batish, D.R., Singh, H.P., Saxena, D.B., Kohli, R.K. and Arora, V. (2002 ). Effect of Parthenin-a sesquiterpene lactone from Parthenium hysterophorus, on early growth and physiology of Ageratum conizoides. J. Chem. Eco. 28: 2169-2179.

8. Barnes, J., Anderson, I.A. and Phillipson, J.D. (2007). Herbal Medicines London, U.K.; Published by the Pharmaceutical Press, RPS Publishing.

9. Belz, R.G., Reinhardt, C.F., Foxcroft, L.C. and Hurle, K. (2007). Residue allelopathy in Parthenium hysterophorus L.-Does parthenin play a leading role? Crop Prot. 26: 237-245.

10.Bhadoria, P.B.S. (2011). Allelopathy; A natural way towards weed management. Ame. J. Exp. Agri, 1(1): $7-20$.

11.Bhatt, B.P., Chauhan, D.S. and Todaria, N.P. (1994). Effects of weed leachates on germination and 
radicle extension of some food crops. Ind. J. Plan. Phy. 37: 177-179.

12.Bhowmik, P.C., Sarkar, D. and Yaduraju, N.T. (2007). The status of Parthenium hysterophorus and its potential management. Ecop. 14: 1-17.

13.Biswas, O. (2010). Allelopathic effects of plant debris of Parthenium weed on seed germination, growth and development of field crops. M.S. Thesis, Submitted to the Department of Agronomy, BAU.

14.Choesin, D.N. and Boerner, R.E.J. (1991). Allylisothiocyanate release and the allelopathic potential of Brassica napus. Amer. J. Bot. 78:1083-1090.

15. Clarence, J.M., Mokiti, T.T. and Patrick, A.N. (2013). Allelopathic effect of Parthenium hysterophorus on seed germination, seedling growth, fresh and dry mass production of Alysicarpus glumaceus and Chloris gayana. Amer. J. Res. Comm. 1(11): 190-205.

16.Demissie, A.G., Ashenafi, A., Arega, A., Etenash U., Kebeda A. and Tigist, A. (2013). Effect of Parthenium hysterophorus $\mathrm{L}$. on germination and elongation of onion (Allium cepa) and Bean (Phaseolus vulgaris). Res. J. Chem. \& Env. Sci. 1(2): $17-21$

17.Devi, O.I. and Dutta, B.K. (2012). Allelopathic effect of the aqueous extract of Parthenium hysterophorus and Chromolaena odorata on the seed germination and seedling vigour of Zea mays L. in vitro. App. J. PI. Sci. 5(4):110-113.

18.Devi, Y.N., Dutta, B.K. Sagolshemcha, R. and Singh, N.I. (2014). Allelopathic effect of Parthenium hysterophorus L. on growth and productivity of Zea mays L. and its phytochemical screening. Int. J. Curr. Micro. \& App. Sci. 3(7): 837-846.

19.Dogra, K. S. and Sood, S. K. (2012). Phytotoxicity of Parthenium hysterophorus residues towards growth of three native plant species (Acacia catechu Wild, Achyranthes aspera L. and Cassia tora L.) in Himachal Pradesh, India. Int. J. Pl. Phy. \& Biochem. 4(5): $105-109$

20.Gnanavel, I. and Natarajan, S.K. (2013). Parthenium hysterophorus L.: A major threat to natural and agro eco-system in India. Sci. Int. 1: 186-193.

21.Guzman, C.D. (1988). Allelopathic effects of seven weed species in pumpkin (Cucurbita moschata) under green house conditions. J. Agri. 72:491-493.

22.Jarvis, B.B., Pena, N.B., Rao, M.M., Comezoglu, R.S., Comezoglu, T.F., and Mandeva, N.B. (1985). Allelopathic agents for Parthenium hysterophorus and Baccharis megapotamica. In: The chemistry of allelopathy, biochemical interactions among the plants. Ame. Chem. Soci.149-159.

23.Karim, S. M. R. and Forzwa. R. (2010). Allelopathic effects of Parthenium weed on the seed germination and seedling growth of field crops. Abstract, Annual Botanical conference held at Chittagong University, Bangladesh during 9 to 10 January, 2010, pp: 38- 39

24.Kathiresan, R.M., Gnanavel, I., Anbhazhagan, R., Padmaria, S.P., Vijayalakshmi, N.K., and Arulchezhian, M.P. (2005). Ecology and control of Parthenium invasion in command area. In: Proceedings of Second International Conference on Parthenium Management. 5-7 Dec. Bangalore, India. 77-80.

25.Kaur, M., Aggarwal, N.K., Kumar, V. and Dhiman, R. (2014). Effects and management of Parthenium hysterophorus: A weed of global significance. Inter. Schol. Res. Noti. 1-12.

26.Khan, N., Hashmatullah, K., Naveed, Z.H. and Khan, S.A. (2012). Assessment of allelopathic effects of
Parthenium (Parthenium hysterophorus L.) plant parts on seed germination and seedling growth of wheat (Triticum aestivum L.) cultivars. Pakis. J. W. Sci. Res. 18(1):39-50.

27.Khalaj, M.A., Amiri, M. and Azimi, M.H. (2013). Allelopathy; Physiological and sustainable agriculture impact aspects. Int. J. Agro. \& PI. Prot, 415: 950 962.

28.Kohli, R.K., Kumari, A. and Saxena, D.B. (1985). Auto-and teletoxicity of Parthenium hysterophorus L. Acta Universitatis Agriculturae Brno [Czechoslovakia] 33: 253-263.

29.Kumar, S. (2012). Current Spread, Impact and Management of Parthenium weed in India. Int. Par. N. 5: $1-6$.

30.Kumar, S. (2015). Allelopathic effects of aqueous extract of leaves of Abutilon indicum (L.) Sweet and Parthenium hysterophorus $\mathrm{L}$. on seed germination and seedling growth of barley. Int. J. Phar. \& Bio. Sci.6(4).1117-1120.

31.Kumar, A., Kumar, P., Ajayan, M.P. and John, G. (2008). Silver nanoparticle embedded antimicrobial paints based on vegetable oil. Nat. Mat. 7: 236-241.

32.Kumar, M. and Kumar, S. (2010). Effect of Parthenium hysterophorus ash on growth and biomass of Phaseolous mungo. Aca. Are. 2(1): 98-102.

33.Maharajan, S., Shrestha, B. B. and Pramod, K. J. (2007): Allelopathic effects of aqueous extract of leaves of Parthenium hysterophorus L. on seed germination and seedling growth of some cultivated and wild herbaceous species. Sci. Wor. 5(5): $234-243$.

34.Marwat, S.K., Rehman F. and Khan IU. (2015). Ethnobotanical importance and phytochemical constituents of Parthenium weed (Parthenium hysterophorus L.) - A Review. PI. Sci. Tod. 2(2): 77-81.

35.Mersie, W. and Singh, M. (1988). Effect of phenolic acids and ragweed Parthenium (Parthenium hysterophorus) extract on tomato (Lycopersicon esculentum) growth and nutrients and chlorophyll content. $W$. Sci. 36: 278-281.

36.McGinley, M. and Duffy, J.M. (2011). "Invasive species." In: Encyclopedia of Earth, Cutler J. Leveland (Ed.) Washington, D.C.: Environmental Information Coalition, National Council for Science and the Environment.

37.Netsere, A. (2015). Allelopathic effect of aqueous extracts of an invasive alien weed Parthenium hysterophorus $L$. on maize and sorghum seed germination and seedling growth. J. Bio, Agri. Hel. 5(1): 120-124.

38. Netsere, A. and Mendesil, E. (2011). Allelopathic effect of Parthenium hysterophorus L. aqueous extract on soybean (Glycine max L.) and haricot bean (Phaseolus vulgaris L.) seed germination, shoot and root growth and dry matter production. J. App. Bot. \& F. Qua. 84: 219 - 222

39.Nguyen, T., Bajwa, A.A., Navie, S., O'Dannell, C and Adkins, S. (2017). Parthenium weed (Parthenium hysterophorus) and climate change: The effect of $\mathrm{CO} 2$ concentration, temperature and water deficit on growth and reproduction of two biotypes. Env. Sci. \& Poll. Res., 24(11): 10727-10739.

40. Oudhia, P. (1998). Parthenium: A curse for the biodiversity of Chhattisgarh plain. In: An Impact on Environment [Abstract] In: National Research Seminar on Bio-chemical Changes on 30-31 July. Mandlaa (M.P.). 26.

41.Oudhia, P., Kohli, S.S. and Tripathi, R.S. (1997). 
Allelopathic effect of white top (Parthenium hysterophorus L.) on chickpea. Leg. Res.20 (2):117-120.

42.Oudhia, P. and Tripathi, R.S. (1998). Allelopathic effects of Parthenium hysterophorus L., on kodo, mustard and problematic weeds. 136-139. In: Proceedings of the First International Conference on Parthenium Management, University of Agricultural Sciences, Dharwad, India, 6-8,October, 1997.

43.Pandey, D. K. (1994). Inhibition of salvinia (Salvinia molesta Mitchell) by Parthenium (Parthenium hysterophorus L.) 2. Relative effect of flower, leaf, stem and root residue on Salvinia and paddy. J. Che. Eco. $20: 3123-3131$

44.Pandey, D.K. (1996). Phytotoxicity of Sesquiterpene lactone parthenin on aquatic weeds. J. Chem. Ecol, 22: 151-160.

45.Pareek, A., Suthar, M., Rathore, G.S. and Bansal, V. (2011). Feverfew (Tanacetum parthenium L.): A systematic review. Pharm. Rev. 5: 103-110.

46.Patil, T. M. and Hedge, B. A. (1988). Isolation and purification of a sesquiterpene lactone from the leaves of Parthenium hysterophorus L. its allelopathic and cytotoxic effects. Curr. Sci. 57: 1178 1181.

47.Parsons, W.T. and Cuthbertson, E.G. (2001). Noxious Weeds of Australia CSIRO Publishing.

48.Peters, E.J. and Zam, A.H.B.M. (1981). Allelopathic effects of trace fescus genotypes. Agro. J. 73:56-59.

49.Picman, J. and Picman, A.K. (1984). Autotoxicity in Parthenium hysterophorus and its possible role in control of germination. Biochem. Syst. \& Eco. 12: 287-292.

50.Purohit, S. and Pandya, N. (2013). Allelopathic activity of Ocimum sanctum $L$. and Tephrosia purpurea (L.)Pers. leaf extracts on few common legumes and weeds. Int. J. Res. P. Sci. 3(1):5-9.

51.Rai, P.K. (2013). Plant Invasion Ecology: Impacts and Sustainable Management. Nova Science Publisher, New York, USA.

52.Rai, P.K. (2015). What makes the plant invasion possible? Paradigm of invasion mechanisms, theories and attributes. Env. Skept. \& Cri. 4(2): 36-66.

53.Rajendiran, K. (2005). Simple and rapid squash schedule for the root tips of Helianthus annus to determine the environmental clastogens. J. Ecotoxi. \& Env. Monit. 15: 291-295.

54.Rajiv, P., Narendhran, S. and Subhash, K.M. (2013). Parthenium hysterophorus L. compost: Assessment of its physical properties and allelopathic effect on germination and growth of Arachis hypogaea L. Int. Res. J. Env. Sci. 2(2): 1-5.

55.Rao, R.S. (1956): Parthenium hysterophorus Linn. A new record. Ind. J. Bom. N. His. Soc. 54:218 - 220.

56.Ranasinghe, R.L.D.S. and Ediriweera, E.R.H.S.S. (2017). Medicinal and nutritional values of Macrotyloma uniflorum (Lam.) verdc (Kulattha): A conceptual study. Glo. J. Pha. \& Pharm. Sci. 1(2): 1-10.

57.Rashid, H., Khan, M. A., Amin, A., Nawab, K., Hussain, N. and Bhowmik, P. K. (2008). Effect of Parthenium hysterophorus L. root extracts on seed germination and growth of maize and barley. The Ame. J. Pl. Sci. Biotech. 51-55.

58.Sarita, K., Abhay, P.S., Gokul, N., Sahil, B., Anubha, S., Naim, W. and Radhika, W. (2011). Impact of Parthenium hysterophorus leaf extracts on the fecundity, fertility and behavioural response of Aedes aegypti $\mathrm{L}$. Parasi. Res.108.2011.853-859.
59.Sharma, G.L. and Bhutani, K.K. (1988). Plant based antiamoebic drugs. Part 2. Amoebicidal activity of Parthenin isolated from Parthenium hysterophorus. Pl. Medi. 54: 20-22.

60.Shikha, R. and Jha, A.K. (2016a). Evaluation of effect of leaf extract of Parthenium hysterophorus L. on seed germination, seedling growth and fresh weight of Phaseolous mungo. Am. J. Res. Comm. 4(2):86103.

61.Shikha, R. and Jha, A.K. (2016b). Allelopathic effect of leaf extract of Parthenium hysterophorus L. on seed germination and growth of Cicer aeritinum L. Int. J. Sci. Res. 5(3):652-655.

62.Shikha, R. and Jha, A.K. (2016c). Allelopathic activity of Parthenium hysterophorus L. leaf extract on Pisum sativum. Int. J. Rec. Sci. Res. 7(3). 9461-9466.

63.Shikha, R. and Jha, A.K. (2016d). Leaf extract of Parthenium hysterophorus $\mathrm{L}$. affects the growth of Cajanus cajan (L.) Millsp. (Quest Journals) J. Res. Agri \& Ani Sci. 4(6): 01-07.

64.Shikha, R. and Jha, A.K. (2017a). Allelopathic influence of aqueous stem extract of Parthenium on growth of maize. Ind. J. W. Sci. 49(2): 1-2.

65.Shikha, R. and Jha, A.K. (2017b). Phytotoxic effects of aqueous stem extract of Parthenium hysterophorus $\mathrm{L}$. on seed germination and seedling growth on Pisum sativum. Poll. Res. 36(4): 153-159.

66.Shikha, R. and Jha, A.K. (2018 a). Evaluation of phytotoxicity levels of Parthenium hysterophorus L. on seed germination and seedling growth of Brassica nigra. International Journal of Basic and Applied Research, 8(8): 399-406.

67.Shikha, R. and Jha, A.K. (2018 b). Evaluation of phytotoxicity levels of Parthenium hysterophorus on Triticum aestivum, Int. J. of Cr. Res. Th., 1404-1408.

68.Singh, S.P. and Sangeeta. (1991). Allelopathic potential of Parthenium hysterophorus L. J. Agro. \& Crop. Sci. 167: 201-206.

69.Singh, N.B. and Thapar, R. (2003). Allelopathic influence of Cannabis sativa on growth and metabolism of Parthenium hysterophorus. Allelo. J., 12(1): $61-70$.

70.Singh, H.P., Batish, D.R., Setia, N and Kohli, R.K. (2005). Herbicidal activity of volatile oils from Eucalyptus citriodora against Parthenium hysterophorus. Anl. App. Bio, 146: 89-94.

71.Singh, R., Chaurasia, S., Gupta, A.D. and Soni, P. (2014). Studies on effect of Parthenium hysterophorus plants extract on germination and growth in certain pulses. Scholarly J. Agri. Sci. 4(4): 235-239.

72.Sorecha, E.M. and Bayissa, B. (2017). Allelopathic effect of Parthenium hysterophorus $\mathrm{L}$. on germination and growth of peanut and soybean in Ethiopia. $A d v$. Crop. Sci. Tech. 5(3): 1-4.

73.Srivastava, J.N., Shukla, J.P. and Srivastava, R.C. (1985). Effect of Parthenium hysterophorus Linn. extract on the seed germination and seedling growth of barley, pea and wheat. Acta Bot. Indi, 13: 194-197.

74.Tafera, T. (2002): Allelopathic effect of Parthenium hysterophorus extracts on seed germination and seedling growth of Eragrostis tef. J. Agro. Cr. Sci. 188: $306-310$.

75.Tamado, T. (2000). Weed flora in arable fields of eastern Ethiopia with emphasis on the occurrence of Parthenium hysterophorus. Int. J. W. Sci. 6: 8507603.

76.Tamado, T., Ohlander, L. and Milberg, P. (2002). 
Shikha, R. and Jha, A.K. / J. Appl. \& Nat. Sci. 10 (4): 1141 -1148 (2018)

Interference by the weed Parthenium hysterophorus L. with grain sorghum: Influence of weed density and duration of competition. Int. J. Pes. Manag., 48:183- 188

77. Upadhyay, S.K., Ahmad, M. and Singh, A. (2013). Ecological impacts of weed (Parthenium hysterophorus L.) invasion in saline soil. Int. J. Sci. \& Res. Publ. $3(4): 1-4$.

78.Veena, B., Kushwaha and Maurya, S. (2012). Biological utilities of Parthenium hysterophorus. J. App. \& Nat. Sci. 4(1): 137-143.

79.Wakjira, M. (2009): Allelopathic effect of Parthenium hysterophorus $\mathrm{L}$. on onion germination and growth. Allelo. J. 24:351 - 362.
80.Wakjira, M., Berecha, G. and Bulti, B. (2005): Allelopathic effect of Parthenium hysterophorus extracts on seed germination and seedling growth of lettuce. Tro. Sci. 45: 159 - 162.

81.Wakjira, M., Berecha, G. and Tulu, S. (2009). Allelopathic effects of an invasive alien weed Parthenium hysterophorus $\mathrm{L}$. compost on lettuce germination and growth. Afri. J. Agri. Res. 4(11): 1325-1330.

82.Zhou, J., Xie, G. and Yan, X. (2011). Encyclopedia of traditional chinese medicines - molecular structures, pharmacological activities, natural sources and applications. Vol. 3: Isolated Compounds H-M, Berlin, Heidelberg: Springer Berlin Heidelberg. 